\title{
Co-liquefaction of microalgae and lignocellulosic biomass in subcritical water
}

\author{
Chao Gai ${ }^{a}$, Yi Li ${ }^{b}$, Nana Peng ${ }^{a}$, Aonan Fan ${ }^{a}$, Zhengang Liu ${ }^{\mathrm{a}, *}$ \\ ${ }^{a}$ Research Center for Eco-Environmental Sciences, Chinese Academy of Sciences, 18 Shuangqing Road, Beijing 100085, PR China \\ ${ }^{\mathrm{b}}$ State Key Laboratory of Multiphase Complex Systems, Institute of Process Engineering (IPE), Chinese Academy of Sciences (CAS), Beijing 100190, PR China
}

\section{H I G H L I G H T S}

- Co-liquefaction of C. pyrenoidosa and rice husk in subcritical water.

- Effects of operation conditions and combined mass ratio on product distribution.

- Major chemical compositions of the bio-crude oils were identified.

- A positive synergistic interaction was observed during the co-liquefaction process.

\section{A R T I C L E I N F O}

\section{Article history:}

Received 5 February 2015

Received in revised form 28 February 2015

Accepted 2 March 2015

Available online 7 March 2015

\section{Keywords:}

Microalgae

Lignocellulosic biomass

Hydrothermal liquefaction

Bio-oil

\begin{abstract}
A B S T R A C T
This study investigated co-liquefaction of microalgae (Chlorella pyrenoidosa, CP) and lignocellulosic biomass (Rice husk, $\mathrm{RH}$ ) in subcritical water for bio-oil production. The effects of liquefaction temperature $\left(200-350^{\circ} \mathrm{C}\right)$, residence time $(10-90 \mathrm{~min})$, solid concentration $(10-30 \mathrm{wt} . \%)$ and mass ratio of $\mathrm{CP} / \mathrm{RH}$ on product distribution were investigated. The results showed that the highest yield of bio-crude oils at the combination of $50 \% \mathrm{CP}$ with $50 \% \mathrm{RH}$ was obtained at $300{ }^{\circ} \mathrm{C}$ temperature, 60 min residence time and $20 \mathrm{wt} . \%$ solid concentration. The oil yields increased gradually with the increased mass ratio of $\mathrm{CP} /$ $\mathrm{RH}$. The major compounds identified in bio-crude oils from hydrothermal liquefaction (HTL) of RH were cyclic oxygenates (20.62\%), followed by esters, ketones and alcohols (17.19\%). As for CP, the main components were straight $\&$ branched amides (28.38\%). A synergistic interaction was observed between $\mathrm{CP}$ and RH during co-liquefaction, resulting in decreased acidity and nitrogen content of bio-crude oils.

(c) 2015 Elsevier Ltd. All rights reserved.
\end{abstract}

\section{Introduction}

Energy crisis has intensified over recent years due to the unrestrained exploitation of fossil fuels. To ensure energy security and reduce our appetite for fossil fuels, renewable energy in terms of solar, wind and biomass have gained increasing attention. Biomass is a cheap and abundant renewable source, which can be converted into biofuels through two main technologies: thermo-chemical conversion such as pyrolysis, gasification and liquefaction, and bio-chemical conversion like anaerobic digestion and alcoholic fermentation (Scholz et al., 2013). Liquefaction of biomass in sub- or supercritical water, which is also called hydrothermal liquefaction (HTL), offers several potential advantages, including high conversion efficiency, high throughputs, and

\footnotetext{
* Corresponding author at: 18 Shuangqing Road, Beijing 100085, PR China. Tel./fax: +861062912718.

E-mail address: zgliu@rcees.ac.cn (Z. Liu).
}

the ability to use mixed feedstock without drying (Kanaujia et al., 2014; Peterson et al., 2008).

In recent years, algal biomass has been recognized as one of the most promising feedstocks for biofuel production, especially for microalgae. Many studies have been carried out concerning hydrothermal processing of microalgae for bio-oil production (Anastasakis and Ross, 2015; Jazrawi et al., 2015; Tommaso et al., 2015; Gai et al., 2014; Toor et al., 2013). Recently, several papers have been published concerning the co-liquefaction of microalgae with other uneasily degradable materials like coal or synthetic polymer (Pei et al., 2012; Yuan et al., 2009). The results indicate that the presence of microalgae enhanced the conversion efficiency, alleviated the reaction conditions and improved the quality of products. Lignocellulosic biomass is the most widely used feedstock for bio-oil production via HTL such as berley straw (Zhu et al., 2015) and miscanthus (Hafez and Hassan, 2015). Previous studies indicate that the bio-oil yield of hydrothermal processing of algal biomass is usually higher than that of lignocellulosic biomass. According to Huang et al. (2013), microalgae of Spirulina and 
lignocellulosic biomass of rice straw were liquefied in subcritical ethanol under identical operating conditions, and it was observed that the biocrude oil yield for Spirulina (34.5\%) was higher than that of rice husk (21.1\%). The different oil yields were ascribed to the different major components of these two kinds of biomass. Proteins, lipids and carbohydrates are the major composition of microalgae, which are less thermal resistant compared to those of main components of lignocellulosic biomass including cellulose, hemicellulose and lignin (Karagöz et al., 2005). Besides, the conversion rates of lipid and protein are higher than those of cellulosic and lignin in hydrothermal environment (Biller and Ross, 2011; Gai et al., 2014; López-González et al., 2014). Therefore, it is expected that the co-liquefaction of microalgae and lignocellulosic biomass may also promote the efficiency in converting two renewable resources into sustainable biofuels.

Extensive studies have been carried out about HTL of microalgae or lignocellulosic biomass in literature. However, to the best of our knowledge, few information is available about the coliquefaction of these two biomass feedstock. Therefore, this study aims to explore the co-liquefaction of microalgae (Chlorella pyronoidosa, $\mathrm{CP}$ ) and lignocellulosic biomass (rice husk, $\mathrm{RH}$ ) for bio-crude oil production. The effects of operating conditions and combined mass ratio on the co-liquefaction characteristics of $\mathrm{CP}$ and $\mathrm{RH}$ were investigated. The operating conditions for bio-crude oil production were optimized, and the main composition of oil compounds was analyzed. In addition, the interactions between $\mathrm{CP}$ and $\mathrm{RH}$ were determined during co-liquefaction process.

\section{Experimental}

\subsection{Materials}

C. pyronoidosa $(\mathrm{CP})$ and rice husk $(\mathrm{RH})$ were selected as representative microalgae and lignocellulosic biomass in the present study. Powder CP was purchased from a health-food store as food-grade material (NOW FOODS, Bloomingdale, IL) and RH was locally obtained with the pretreatment of crushing and sieving. The moisture, volatile content, ash and calorific value of the materials were determined following standards ISO 589:2003, ISO 562:2010, ISO 1171:2010 and ISO 1928:2009, respectively. Elemental analysis of $\mathrm{CP}$ and $\mathrm{RH}$ was conducted on an elemental analyzer (CE-440, Exeter Analytical Inc., North Chelmsford, MA). The chemical compositions were determined according to the methods of the Association of Official Analytical Chemists $(A O A C)$. Table 1 presented the properties of two feedstock.

\subsection{Experimental procedure and characterization}

In the present study, three stainless autoclave with $100 \mathrm{ml}$ capacity were applied to the HTL experiments. During each test, $30 \mathrm{~g}$ feedstock slurries with biomass and deionized water were added to the reactor. The reactor was sealed and then was heated by an electric heater up to a preset temperature and maintained for a certain residence time based on the experimental design. Finally, the reactor was cooled down to room temperature. The gas in the reactor was first sampled into a Tedlar $^{\circledR}$ gas sampling bag (CEL Scientific CORP., Cerritos, USA) through a control valve. Afterwards, the reactor was opened and the remaining mixture was separated by physical filtration using a Whatman ${ }^{\circledR} 55 \mathrm{~mm}$ glass-fiber filter (Whatman ${ }^{\circledR}$, Cat, No. 1822-055). The watersoluble portion was defined as the aqueous fraction while the left product was defined as the raw oil. Soxhlet extraction using the solvent of toluene was used to extract the toluene soluble fraction from the raw oil, which was defined as the bio-crude oil in the present study. The toluene insoluble fraction was then oven dried
Table 1

Proximate, ultimate and chemical analysis of the $\mathrm{CP}$ and $\mathrm{RH}$.

\begin{tabular}{|c|c|c|c|c|}
\hline & $\mathrm{CP}$ & References & RH & References \\
\hline \multicolumn{5}{|c|}{ Proximate analysis (d.wt.\%) } \\
\hline Volatile matter & 94.3 & $\begin{array}{l}94.4 \text { (Yu et al., } \\
\text { 2011) }\end{array}$ & 81.1 & $\begin{array}{l}81.2 \text { (Mansaray and } \\
\text { Ghaly, 1998) }\end{array}$ \\
\hline Ash & 5.7 & $\begin{array}{l}5.6 \text { (Yu et al., } \\
2011)\end{array}$ & 18.9 & $\begin{array}{l}18.8 \text { (Mansaray and } \\
\text { Ghaly, 1998) }\end{array}$ \\
\hline \multicolumn{5}{|c|}{ Elemental composition (d.wt.\%) } \\
\hline Carbon & 51.2 & $\begin{array}{l}51.4 \text { (Yu et al., } \\
2011 \text { ) }\end{array}$ & 41.6 & 43.1 (Liu et al., 2013) \\
\hline Hydrogen & 6.8 & $\begin{array}{l}6.6 \text { (Yu et al., } \\
2011 \text { ) }\end{array}$ & 5.2 & 6.1 (Liu et al., 2013) \\
\hline Nitrogen & 11.3 & $\begin{array}{l}\text { 11.1 (Yu et al., } \\
\text { 2011) }\end{array}$ & 4.7 & 4.3 (Liu et al., 2013) \\
\hline Oyxgen $^{a}$ & 30.7 & $\begin{array}{l}30.9 \text { (Yu et al., } \\
2011 \text { ) }\end{array}$ & 48.5 & 46.6 (Liu et al., 2013) \\
\hline \multicolumn{5}{|c|}{ Chemical composition (d.wt.\%) } \\
\hline Protein & 71.5 & $\begin{array}{l}71.3 \text { (Yu et al., } \\
2011 \text { ) }\end{array}$ & - & - \\
\hline Lipid & 0.2 & $\begin{array}{l}0.1 \text { (Yu et al., } \\
2011 \text { ) }\end{array}$ & - & - \\
\hline $\begin{array}{l}\text { Non-fibrous } \\
\text { carbohydrates }\end{array}$ & 22.5 & $\begin{array}{l}22.0 \text { (Yu et al., } \\
2011 \text { ) }\end{array}$ & - & - \\
\hline Cellulose & - & - & 29.2 & $\begin{array}{l}25.9 \text { (Mansaray and } \\
\text { Ghaly, 1998) }\end{array}$ \\
\hline Hemicellulose & - & - & 20.1 & $\begin{array}{l}18.1 \text { (Mansaray and } \\
\text { Ghaly, 1998) }\end{array}$ \\
\hline Lignin & - & - & 28.2 & $\begin{array}{l}31.4 \text { (Mansaray and } \\
\text { Ghaly, 1998) }\end{array}$ \\
\hline
\end{tabular}

\footnotetext{
a By difference.
}

and viewed as the solid residue. The chemical compositions of biocrude oil were analyzed using GC/MS (Agilent 7890A GC-5975C MS, Agilent Technologies, USA) equipped with flame ionization detector (FID) and HP-5 column. Pentadecanoic acid, methyl ester was selected as the internal standard for bio-crude oil. The main peaks in the total ion chromatograms of the bio-crude oil were identified using an NIST mass spectral database (NIST08).

\section{Results and discussion}

\subsection{Effect of temperature on product distribution}

During hydrothermal processing, temperature is the most important factor affecting product distribution (Peterson et al., 2008; Gai et al., 2015). Consequently, the effect of temperature was firstly valued on the product distribution from co-liquefaction

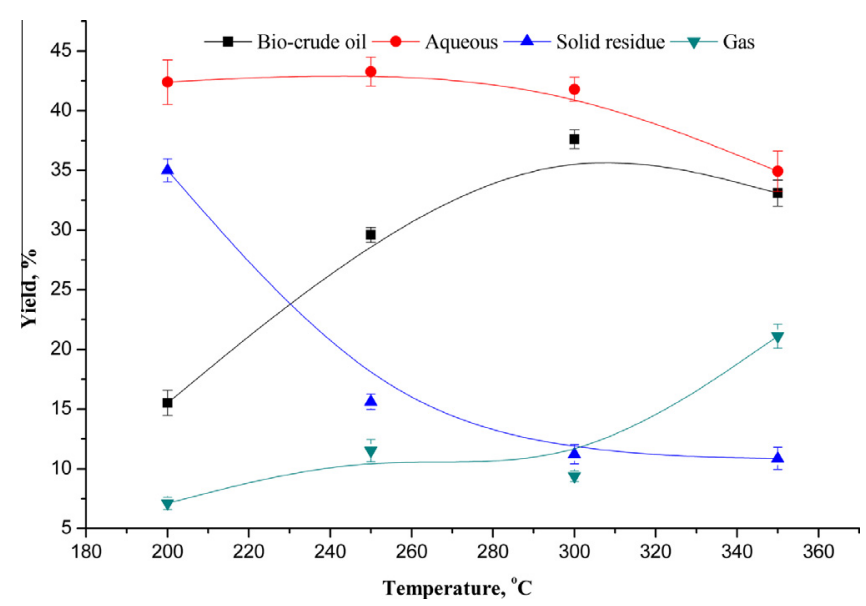

Fig. 1. Effect of temperature on product distribution (at $20 \mathrm{wt} . \%$ solid concentration, 60 min residence time and the combination of $50 \% \mathrm{CP}$ with $50 \% \mathrm{RH}$ ). 
of $\mathrm{CP}$ and $\mathrm{RH}$. The aqueous fractions were calculated by difference in the present study. Fig. 1 illustrated the effect of temperature on the distribution of products at $20 \mathrm{wt}$ \% solid concentration, $60 \mathrm{~min}$ residence time and the combination of $50 \% \mathrm{CP}$ with $50 \% \mathrm{RH}$. With the increment of temperature from 200 to $350{ }^{\circ} \mathrm{C}$, the yields of different products had various trends. Specifically, the yield of bio-crude oil increased from $15.5 \%$ at $200{ }^{\circ} \mathrm{C}$ to $37.6 \%$ at $300{ }^{\circ} \mathrm{C}$, and then decreased slightly to $33.1 \%$ at $350{ }^{\circ} \mathrm{C}$. The yield of solid residue was decreased with the increasing temperature from $34.9 \%$ at $200{ }^{\circ} \mathrm{C}$ to $10.8 \%$ at $350{ }^{\circ} \mathrm{C}$, while in the case of the gaseous product, its yield gradually increased from $7.1 \%$ at $200{ }^{\circ} \mathrm{C}$ to $21.1 \%$ at $350^{\circ} \mathrm{C}$.

It can be seen in Fig. 1 that when the temperature exceeded the specific point $\left(300^{\circ} \mathrm{C}\right)$, more gas products were generated while the bio-crude oil yields decreased slightly. This is because at temperatures lower than $300{ }^{\circ} \mathrm{C}$, organic matters in the samples are more thermally degraded into oil phase while with further increased temperature, polymerization reactions of intermediates to form the char are dominated, resulting in decreased bio-crude oil yields. In addition, secondary decompositions may be triggered to transform some bio-crude oils into gaseous compounds at high temperatures (Valdez et al., 2012). It was also verified by the constant increase of gas yield from 300 to $350{ }^{\circ} \mathrm{C}$ in the present study. Chen et al. (2014) investigated the hydrothermal liquefaction of mixed-culture algal biomass from wastewater treatment and it was observed that the gas products greatly increased when the temperature exceeding $300^{\circ} \mathrm{C}$. These trends of product distribution are also consistent with the HTL results of microalgae of Spirulina platensis (Jena et al., 2011) and lignocellulosic biomass of cornelian cherry stone (Akalin et al., 2012). The optimum condition for the yield of bio-crude oil was observed to be $300{ }^{\circ} \mathrm{C}$ for the given reactor. Therefore, this optimum temperature was chosen for studying the effect of residence time.

\subsection{Effect of residence time on product distribution}

Fig. 2 demonstrated the effect of residence time on the distribution of products at $300{ }^{\circ} \mathrm{C}$ temperature, $20 \mathrm{wt} . \%$ solid concentration and the combination of $50 \% \mathrm{CP}$ with $50 \% \mathrm{RH}$. It is clear that with an increase in residence time, bio-crude oil yield increased until $60 \mathrm{~min}$, then decreased slightly with a further increase in residence time. This observation indicates that a 60 min residence time is sufficient for the formation of oil compounds, while a time longer than $60 \mathrm{~min}$ will bring about the further recondensation or repolymerization of bio-crude oils. The yield of solid residue

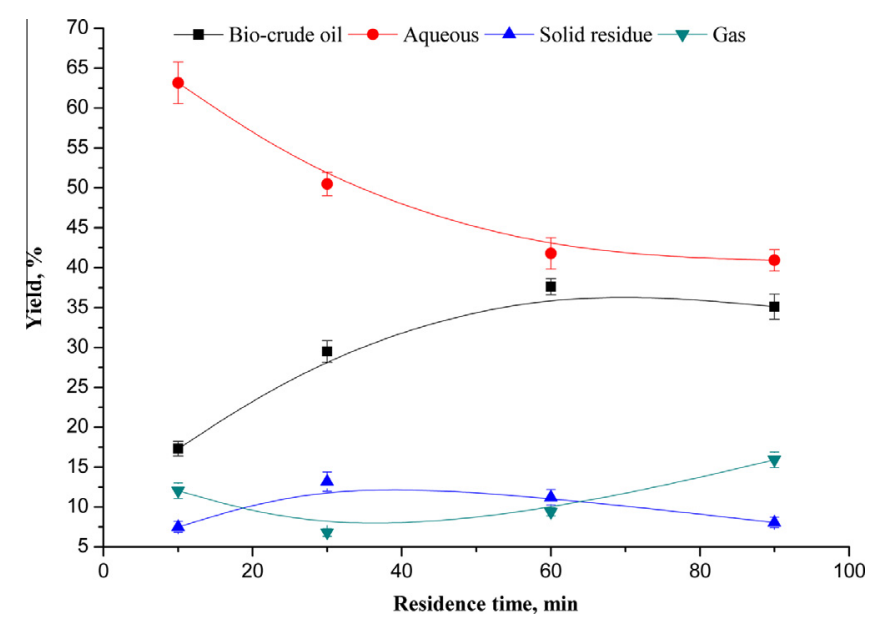

Fig. 2. Effect of residence time on product distribution (at $300{ }^{\circ} \mathrm{C}$ temperature, 20 wt.\% solid concentration and the combination of 50\% CP with 50\% RH). underwent a fall after an increment of residence time from 10 to 90 min while in the case of gaseous product, its yield decreased from 10 to $30 \mathrm{~min}$ and then increased again from 30 to $90 \mathrm{~min}$. Compared to reaction temperature, the residence time showed less effect on the yield variations of solid residue and gaseous product.

The optimum residence time for the oil yield during the HTL process is mainly affected by the chemical composition of the feedstock. For example, HTL of microalgae Dunaliella tertiolecta cake was investigated by Zou et al. (2010), and it was reported that the oil yield increased up to $1 \mathrm{~h}$. However, liquefaction of lignocellulosic biomass of Cunninghamia lanceolata in subcritical water $(\mathrm{Qu}$ et al., 2003) showed that a residence time of $10 \mathrm{~min}$ was enough to produce the highest oil yield. In addition, residence time is also closely linked to reaction temperature and higher temperature requires shorter residence time, and vice versa. For example, during the HTL of microalgae Desmodesmus (Garcia Alba et al., 2012), a residence time of only $5 \mathrm{~min}$ at $375{ }^{\circ} \mathrm{C}$ produced the highest oil yield while a residence time of $120 \mathrm{~min}$ at $280^{\circ} \mathrm{C}$ was optimum for the oil yield during liquefaction of microalgae Chlorella (Yu et al., 2011).

\subsection{Effect of solid concentration on product distribution}

Fig. 3 showed the effect of solid concentration on product distribution at $300{ }^{\circ} \mathrm{C}, 60 \mathrm{~min}$ residence time and the combination of $50 \% \mathrm{CP}$ with $50 \% \mathrm{RH}$. It can be observed that with the increased solid concentration from 10 to $30 \mathrm{wt}$ \%, the yields of bio-crude oil increased slightly then decreased, and the highest yield was achieved at $20 \mathrm{wt} . \%$. In hydrothermal environment the water acts both as a medium of heat-transfer and as a reactant of hydrogen donor. According to Akhtar and Saidina Amin (2011), the increased solid concentration may inhibit the interactions between molecules of biomass and water, suppressing the dissolution of the biomass components. Thus the yield of bio-crude oil was decreased at higher solid concentration. This observation agrees with the reported liquefaction of lignocellulosic biomass of $C$. lanceolata in subcritical water (Qu et al., 2003) and rice husk in subcritical ethanol (Huang et al., 2013). However, as for the liquefaction of brown macro-alga Laminaria saccharina (Anastasakis and Ross, 2011), it was reported that the maximum oil yield was obtained at a solid concentration of $10 \mathrm{wt}$.\% (i.e. $3 \mathrm{~g}$ of seaweed with $30 \mathrm{ml}$ of water) and further increase of solid loading did not influence the yields. It suggests that the effect of solid concentration is also affected by the feedstock chemical composition.

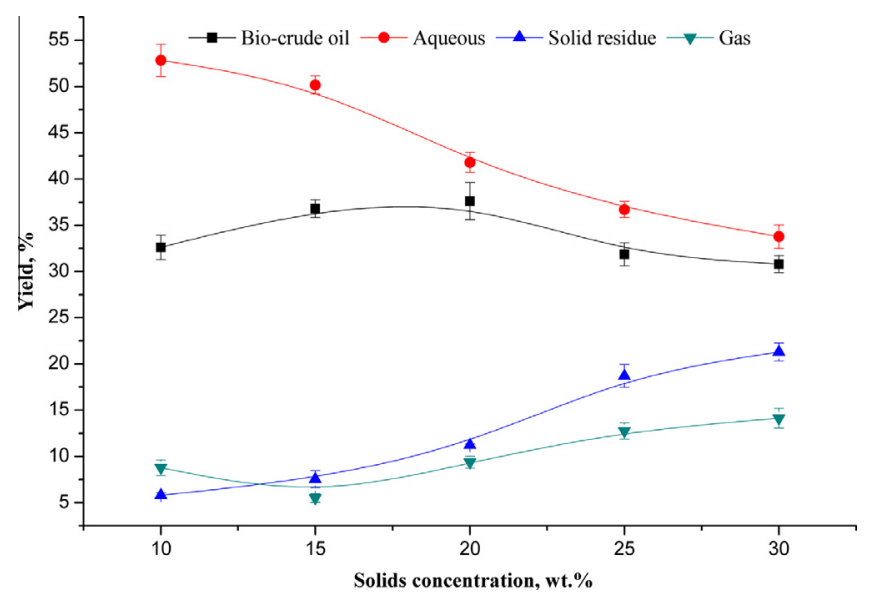

Fig. 3. Effect of solids concentration on product distribution (at $60 \mathrm{~min}$ residence time, $300{ }^{\circ} \mathrm{C}$ temperature and the combination of $50 \% \mathrm{CP}$ with $50 \% \mathrm{RH}$ ). 
The variations of yields for solid residue and gas were similar, which were both increased with the increment of solid concentration. According to Sato et al. (2003), lower solid concentration enhanced the extraction by the denser solvent medium during the HTL process, thus reducing the amount of solid residues and gas.

\subsection{Effect of $C P / R H$ mass ratio on product distribution}

Fig. 4 presented the effect of mass ratio of $\mathrm{CP} / \mathrm{RH}$ on the distribution of products at $20 \mathrm{wt} . \%$ solid concentration, $300{ }^{\circ} \mathrm{C}$ temperature and $60 \mathrm{~min}$ residence time. With the increment of mass ratio of $\mathrm{CP} / \mathrm{RH}$, the bio-crude oil yield increased constantly from $13.9 \%$ at the combination of $0 \mathrm{CP}$ with $100 \% \mathrm{RH}$ to $43.6 \%$ at the combination of $100 \%$ CP with 0 RH. Karagöz et al. (2005) investigated the liquefaction of woody biomass of sawdust and nonwoody biomass of rice husk in the subcritical water at $280^{\circ} \mathrm{C}$ for $15 \mathrm{~min}$ and $16 \mathrm{wt} . \%$ solid concentration. It was reported that the oil yield of rice husk and sawdust was $8.3 \%$ and $8.6 \%$, respectively. Jena et al. (2011) investigated the hydrothermal liquefaction of microalgae of $S$. platensis. It was concluded that the highest biocrude yield of $39.9 \%$ could be obtained at $350{ }^{\circ} \mathrm{C}$ for $60 \mathrm{~min}$ and 20 wt.\% solid concentration. Taking into account the differences in the chemical compositions of biomass material and operating conditions, the result in the present study is consistent with the results obtained in literature.

In the present study, the yields for solid residue gradually decreased from $19.8 \%$ to $1.2 \%$ with increased mass ratio of $\mathrm{CP} / \mathrm{RH}$ from the combination of $0 \mathrm{CP}$ with $100 \% \mathrm{RH}$ to the combination of $100 \% \mathrm{CP}$ with $0 \mathrm{RH}$. The solid residue is mainly composed of ash and bio-char, and Table 1 demonstrated that the ash content for CP and RH was $5.7 \%$ and $18.91 \%$, respectively. The yield of solid residue decreased gradually due to the increased proportion of microalgae with low ash content in the samples. Another reason is that in hydrothermal environment, the composition of lignin contributes more to the formation of solid residue compared to other substituents. According to Karagöz et al. (2005), 60 wt.\% of the lignin were converted into the solid residue in hydrothermal environment, which is far higher than that of cellulose (29.9 wt.\%). It should be noted in Fig. 4 that the variations of yields for gas and aqueous fractions were both not monotonic with the increased mass ratio of $\mathrm{CP} / \mathrm{RH}$. A possible reason may be that during hydrothermal processing, the interactions between $\mathrm{CP}$ and $\mathrm{RH}$ may alter the product distribution, and it indicates that a

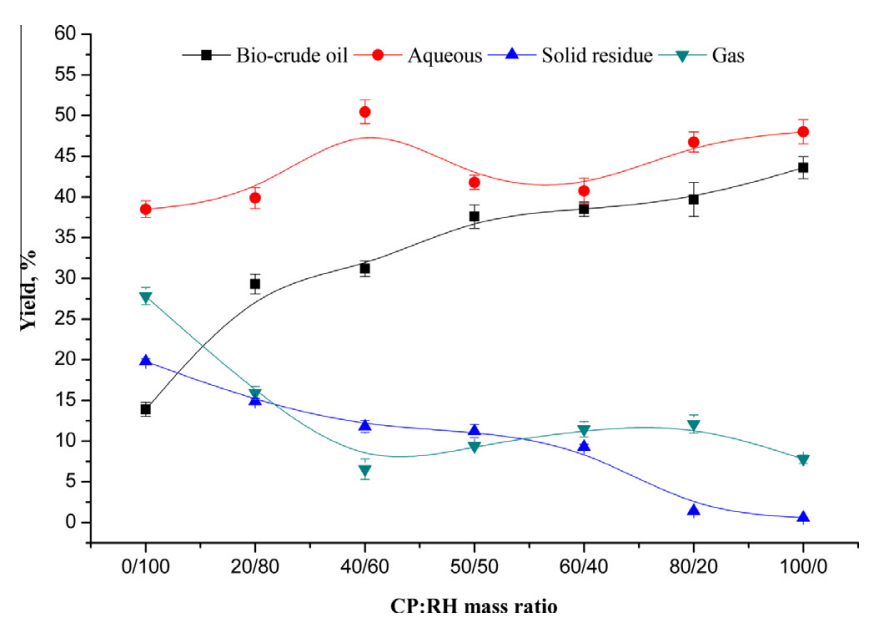

Fig. 4. Effect of mass ratio of $\mathrm{CP} / \mathrm{RH}$ on product distribution (at $300{ }^{\circ} \mathrm{C}$ temperature, $60 \mathrm{~min}$ residence time and $20 \mathrm{wt} . \%$ solid concentration). synergistic interaction may exist during the co-liquefaction process, which is further investigated by GC/MS.

\subsection{Characterization of bio-crude oil}

The seven samples of bio-crude oils obtained at different mass ratios of $\mathrm{CP} / \mathrm{RH}$ were analyzed using $\mathrm{GC} / \mathrm{MS}$ to identify the major components. As shown in Fig. 5, the major compounds identified were categorized into six classes based on the functional groups: (1) hydrocarbons such as alkanes, alkenes and derivatives, (2) organic acids like short-chained acids, aromatic acids or longchained fatty acids, (3) straight \& branched amides, (4) cyclic oxygenates in terms of phenol, phenol derivatives and fused ring compounds, (5) N\&O-heterocyclic compounds, (6) esters, ketones and alcohols. It should be noted that each component was categorized into only one group, although many compounds contained more than one function group. The major components with a relative percentage of peak areas higher than $1 \%$ for the bio-crude oils were available in supplementary information (Table S1).

The mass ratio of $\mathrm{CP} / \mathrm{RH}$ showed different effects on chemical composition of the bio-crude oils. With the increasing percentage of $\mathrm{CP}$ in mixed feedstock from $0 \%$ to $100 \%$ (Sample 1-7), the content of straight \& branched amides and N\&O-heterocyclic gradually increased while the concentration of cyclic oxygenates and esters, ketones and alcohols constantly decreased. The major compounds identified in bio-crude oils from HTL of RH (Sample 1) were cyclic oxygenates (20.62\%). It mainly contained phenolic compounds and its derivatives (i.e. 2-methoxy-phenol and 4-ethyl-phenol), which are likely derived from the lignin of $\mathrm{RH}$. Lignin is one of the major components of the carbohydrates in the lignocellulosic biomass. It is an aromatic heteropolymer consisting of phenylpropanoid compounds in terms of $p$-coumaryl alcohol, coniferyl alcohol and sinapylalcohol. Phenols and methoxy phenols can be formed by hydrolysis of ether-bonds or methoxy groups in the hydrothermal environment. For example, Wahyudiono Kanetake et al. (2007) investigated the lignin model compounds in near-critical water and it was reported that the main products were catechol (40.73\%), phenol (14.18\%) and o-cresol (4.45\%). Karagöz et al. (2005) concluded that lignin-derived oil mainly contained phenolic compounds under hydrothermal treatment. Phenol and its derivatives are also observed to be the major components of the biocrude oils from hydrothermal processing of other lignocellulosic biomass such as bamboo (Yip et al., 2009) and barley straw (Zhu et al., 2015).

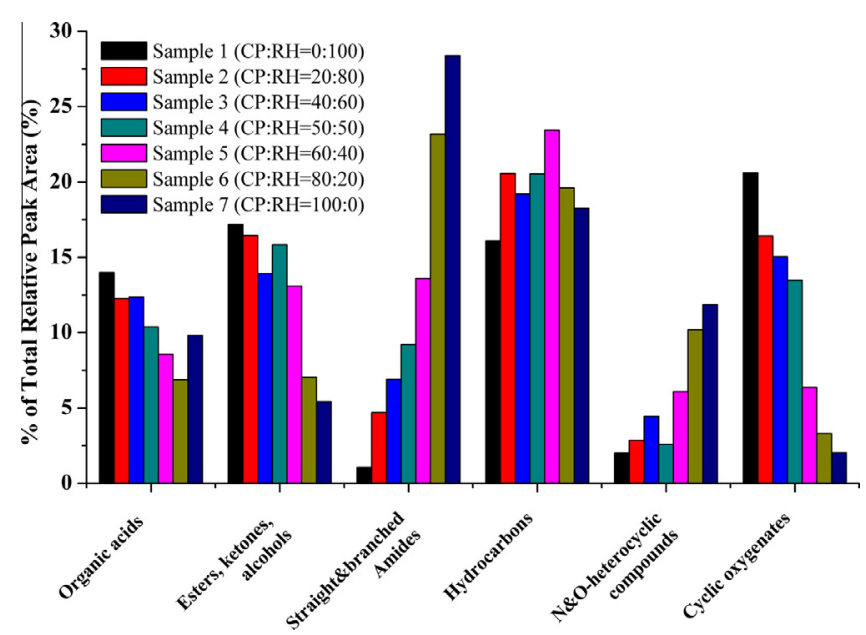

Fig. 5. Distribution of major compounds indentified in bio-crude oils obtained at different mass ratios of $\mathrm{CP} / \mathrm{RH}$ 
In addition, the content of esters, ketones and alcohols (17.19\%) for RH was observed to be higher than other compounds, which are primarily derived from the retro-aldol condensation (Matsuoka et al., 2012) during the hydrothermal liquefaction of cellulose in lignocellulosic biomass. Besides, a certain amount of phenol and derivatives may also be derived from the condensation of cellulose or hemicellulose (Karagöz et al., 2005).

In the case of bio-crude oils of CP (Sample 7), its content of nitrogenous compounds detected was much higher than that of $\mathrm{RH}$ (Sample 1). It is mainly due to the high protein content in CP. Specifically, the straight \& branched amides (28.38\%) were the major compounds for CP (Sample 7). Similar observations have been reported from HTL of Spirulina (Vardon et al., 2011). In hydrothermal environment, protein and lipid are first hydrolyzed to amino acids and long-chained fatty acids, respectively. Afterwards, the hydroxyl groups in fatty acids are replaced by ammonia from deamination of amino acids to produce straight \& branched amides (i.e. hexadecanamide or octadecanamide identified in the present study). Additionally, the content of N\&O heterocyclic compounds of CP was much higher than that of RH. During hydrothermal processing, N\&O-heterocyclic compounds are mainly produced from the Maillard reaction between amino acids from hydrolysis of the proteins in microalgae and reducing sugars from hydrolysis of carbohydrates (Peterson et al., 2008).

It can also be observed in Fig. 5 that the variations of organic acids and hydrocarbons were opposite with respect to the increase of the $\mathrm{CP} / \mathrm{RH}$ mass ratio. This is because the organic acids are mainly formed from the hydrolysis of cellulose and hemicellulose in lignocellulosic biomass or the hydrolysis of proteins and lipids in microalgae. Hydrocarbons are partially produced from organic acids via decarboxylation. Interestingly, with the increase of the $\mathrm{CP} / \mathrm{RH}$ mass ratio, the content of organic acids declined gradually while the hydrocarbons increased correspondingly. For example, the Sample 5 obtained at the combination of $60 \%$ CP with $40 \%$ $\mathrm{RH}$ was observed to have $23.44 \%$ hydrocarbons and $8.57 \%$ organic acids. In addition, the content of cyclic oxygenates $(6.36 \%)$ for Sample 5 was not as high as that of Sample 1 (20.62\%), while the content of straight \& branched amides (13.6\%) and N\&O-heterocyclic compounds $(6.08 \%)$ were far lower than that of sample 7 ( $28.38 \%$ and $11.87 \%$ ), respectively. The decrease of content of organic acids can reduce acidity and improve the HHVs of biocrude oil due to the lower oxygen content, and a higher content of hydrocarbons contributes to higher bio-oil HHVs (Mullen et al., 2009). The lower content of nitrogenous compounds in bio-crude oil is also preferable due to the lower NOx emissions during combustion. Therefore, it can be concluded that a positive synergistic interaction occurred between $\mathrm{CP}$ and $\mathrm{RH}$ during coliquefaction process and as a result, fuel property of the bio-crude oil was significantly improved. Additionally, as shown in Fig. 5 that the six classes of major compounds in bio-crude oils were not linearly proportional to the feedstock combination ratios, implying the complex nature of synergistic interaction. The detailed interaction involved in co-liquefaction between $\mathrm{CP}$ and $\mathrm{RH}$ requires further investigation based on different model compounds of biomass substrates.

\section{Conclusions}

Co-liquefaction of $\mathrm{CP}$ and $\mathrm{RH}$ in subcritical water was investigated, and the maximum yield of bio-crude oils was obtained at $300{ }^{\circ} \mathrm{C}$ temperature, $60 \mathrm{~min}$ residence time and $20 \mathrm{wt} . \%$ solid concentration. Major compounds identified in the bio-crude oil of $\mathrm{RH}$ were cyclic oxygenates while straight \& branched amides were most abundant for that of $\mathrm{CP}$. The optimum bio-crude oil was obtained at $\mathrm{CP} / \mathrm{RH}$ mass ratio of $60 / 40$ and composed of $23.44 \%$ hydrocarbons, $8.57 \%$ organic acids, $13.6 \%$ straight \& branched amides, and $6.08 \% \mathrm{~N} \& \mathrm{O}-$ heterocyclic compounds. The synergistic interaction occurred between $\mathrm{CP}$ and $\mathrm{RH}$ improved the fuel quality of bio-oil.

\section{Acknowledgements}

The authors acknowledge the financial support from the Chinese Academy of Sciences and Beijing Natural Science Foundation (3142020).

\section{Appendix A. Supplementary data}

Supplementary data associated with this article can be found, in the online version, at http://dx.doi.org/10.1016/j.biortech.2015.03. 015 .

\section{References}

Akalin, M.K., Tekin, K., Karagöz, S., 2012. Hydrothermal liquefaction of cornelian cherry stones for bio-oil production. Bioresour. Technol. 110, 682-687.

Akhtar, J., Saidina Amin, N.A., 2011. A review on process conditions for optimum bio-oil yield in hydrothermal liquefaction of biomass. Renew. Sustain. Energy Rev. 15, 1615-1624.

Anastasakis, K., Ross, A.B., 2011. Hydrothermal liquefaction of the brown macroalga Laminaria saccharina: effect of reaction conditions on product distribution and composition. Bioresour. Technol. 102, 4876-4883.

Anastasakis, K., Ross, A.B., 2015. Hydrothermal liquefaction of four brown macro-algae commonly found on the UK coasts: an energetic analysis of the process and comparison with bio-chemical conversion methods. Fuel 139 546-553.

Biller, P., Ross, A.B., 2011. Potential yields and properties of oil from the hydrothermal liquefaction of microalgae with different biochemical content. Bioresour. Technol. 102, 215-225.

Chen, W.-T., Zhang, Y., Zhang, J., Yu, G., Schideman, L.C., Zhang, P., Minarick, M. 2014. Hydrothermal liquefaction of mixed-culture algal biomass from wastewater treatment system into bio-crude oil. Bioresour. Technol. 152 130-139.

Gai, C., Zhang, Y., Chen, W., Zhang, P., Dong, Y., 2014. Energy and nutrient recovery efficiencies in biocrude oil produced via hydrothermal liquefaction of Chlorella pyrenoidosa. RSC Adv. 4, 16958-16967.

Gai, C., Zhang, Y., Chen, W., Zhou, Y., Schideman, L., Zhang, P., Tommaso, G., Kuo, C. Dong, Y., 2015. Characterization of aqueous phase from the hydrothermal liquefaction of Chlorella pyrenoidosa. Bioresour. Technol. 184, 328-335.

Garcia Alba, L., Torri, C., Samori, C., van der Spek, J., Fabbri, D., Kersten, S.R.A., 2012 Hydrothermal treatment (HTT) of microalgae: evaluation of the process as conversion method in an algae biorefinery concept. Energy Fuels 26, 642-657.

Hafez, I., Hassan, E.B., 2015. Rapid liquefaction of giant miscanthus feedstock in ethanol-water system for production of biofuels. Energy Convers. Manage. 91, 219-224.

Huang, H., Yuan, X., Zhu, H., Li, H., Liu, Y., Wang, X., Zeng, G., 2013. Comparative studies of thermochemical liquefaction characteristics of microalgae lignocellulosic biomass and sewage sludge. Energy 56, 52-60.

Jazrawi, C., Biller, P., He, Y., Montoya, A., Ross, A.B., Maschmeyer, T., Haynes, B.S. 2015. Two-stage hydrothermal liquefaction of a high-protein microalga. Algal Res. 8, 15-22.

Jena, U., Das, K.C., Kastner, J.R., 2011. Effect of operating conditions of thermochemical liquefaction on biocrude production from Spirulina platensis. Bioresour. Technol. 102, 6221-6229.

Kanaujia, P.K., Sharma, Y.K., Garg, M.O., Tripathi, D., Singh, R., 2014. Review of analytical strategies in the production and upgrading of bio-oils derived from lignocellulosic biomass. J. Anal. Appl. Pyrol. 105, 55-74.

Karagöz, S., Bhaskar, T., Muto, A., Sakata, Y., Azhar Uddin, Md., 2005. Comparative studies of oil compositions produced from sawdust, rice husk, lignin and cellulose by hydrothermal treatment. Fuel 84, 875-884.

Liu, Y., Yuan, X., Huang, H., Wang, X., Wang, H., Zeng, G., 2013. Thermochemical liquefaction of rice husk for bio-oil production in mixed solvent (ethanolwater). Fuel Process. Technol. 112, 93-99.

López-González, D., Fernandez-Lopez, M., Valverde, J.L., Sanchez-Silva, L., 2014 Kinetic analysis and thermal characterization of the microalgae combustion process by thermal analysis coupled to mass spectrometry. Appl. Energy 114, $227-237$.

Mansaray, K.G., Ghaly, A.E., 1998. Thermal degradation of rice husks in nitrogen atmosphere. Bioresour. Technol. 65, 13-20.

Matsuoka, S., Kawamoto, H., Saka, S., 2012. Retro-aldol-type fragmentation of reducing sugars preferentially occurring in polyether at high temperatures: role of the ether oxygen as a base catalyst. J. Anal. Appl. Pyrol. 93, 24-32.

Mullen, C.A., Strahan, G.D., Boateng, A.A., 2009. Characterization of various fastpyrolysis bio-oils by NMR spectroscopy. Energy Fuels 23, 2707-2718. 
Pei, X., Yuan, X., Zeng, G., Huang, H., Wang, J., Li, H., Zhu, H., 2012. Co-liquefaction of microalgae and synthetic polymer mixture in sub- and supercritical ethanol. Fuel Process. Technol. 93, 35-44.

Peterson, A.A., Vogel, F., Lachance, R.P., Froling, M., Antal, M.J., Tester, J.W., 2008. Thermochemical biofuel production in hydrothermal media: a review of suband supercritical water technologies. Energy Environ. Sci. 1, 32-65.

Qu, Y., Wei, X., Zhang, C., 2003. Experimental study on the direct liquefaction of Cunninghamia lanceolata in water. Energy 28, 597-606.

Sato, T., Osada, M., Watanabe, M., Shirai, M., Arai, K., 2003. Gasification of alkylphenols with supported noble metal catalysts in supercritical water. Ind. Eng. Chem. Res. 42, 4277-4282.

Scholz, M.J., Riley, M.R., Cuello, J.L., 2013. Acid hydrolysis and fermentation of microalgal starches to ethanol by the yeast Saccharomyces cerevisiae. Biomass Bioenergy 48, 59-65.

Tommaso, G., Chen, W.T., Li, P., Schideman, L., Zhang, Y., 2015. Chemica characterization and anaerobic biodegradability of hydrothermal liquefaction aqueous products from mixed-culture wastewater algae. Bioresour. Technol. $178,139-146$.

Toor, S.S., Reddy, H., Deng S., Hoffmann, J., Spangsmark, D, Madsen, L.B., HolmNielsen, J.B., Rosendahl, L.A., 2013. Hydrothermal liquefaction of Spirulina and Nannochloropsis salina under subcritical and supercritical water conditions. Bioresour. Technol. 131, 413-419.

Valdez, P.J., Nelson, M.C., Wang, H.Y., Lin, X.N., Savage, P.E., 2012. Hydrothermal liquefaction of Nannochloropsis sp.: systematic study of process variables and analysis of the product fractions. Biomass Bioenergy 46, 317-331.
Vardon, D.R., Sharma, B.K., Scott, J., Yu, G., Wang, Z., Schideman, L., Zhang, Y., Strathmann, T.J., 2011. Chemical properties of biocrude oil from the hydrothermal liquefaction of Spirulina algae, swine manure, and digested anaerobic sludge. Bioresour. Technol. 102, 8295-8303.

Wahyudiono Kanetake, T. Sasaki, M., Goto, M., 2007. Decomposition of a lignin model compound under hydrothermal conditions. Chem. Eng. Technol. 30, 1113-1122.

Yip, J., Chen, M., Sezto, Y.S., Yan, S., 2009. Comparative study of liquefaction process and liquefied products form bamboo using different organic solvents. Bioresour. Technol. 100, 6674-6678.

Yu, G., Zhang, Y., Schideman, L., Funk, T.L., Wang, Z., 2011. Hydrothermal liquefaction of low lipid content microalgae into bio-crude oil. Trans. ASABE $54,239-246$.

Yuan, X., Cao, H., Li, H., Zeng, G., Tong, J., Wang, L., 2009. Quantitative and qualitative analysis of products formed during co-liquefaction of biomass and synthetic polymer mixtures in sub- and supercritical water. Fuel Process. Technol. 90, 428-434.

Zhu, Z., Toor, S.S., Rosendahl, L., Yu, D., Chen, G., 2015. Influence of alkali catalyst on product yield and properties via hydrothermal liquefaction of barley straw. Energy 80, 284-292.

Zou, S., Wu, Y., Yang, M., Imdad, K., Li, C., Tong, J., 2010. Production and characterization of bio-oil from hydrothermal liquefaction of microalgae Dunaliella tertiolecta cake. Energy 35, 5406-5411. 